\title{
Anthophyllite Asbestos: The Role of Fiber Width in Mesothelioma Induction. Part 4: Mechanistic Considerations regarding the Failure to Observe Anthophyllite Asbestos Mesotheliomas in Humans
}

\author{
Edward B. Ilgren ${ }^{1} \&$ John A. Hoskins ${ }^{2}$ \\ ${ }^{1}$ Visiting Professor of Neuropathology \& Expert Investigator in Environmental Neurotoxicology, University of \\ Tarapaca, Chile. Formerly, University of Oxford, Faculty of Biological \& Agricultural Sciences, Department of \\ Neuropathology, Oxford, UK \\ ${ }^{2}$ Independent Consultant, Haslemere. UK. Formerly, Medical Research Council, Leicester, UK \\ Correspondence: Dr. E. B. Ilgren, Visiting Professor of Neuropathology \& Expert Investigator in Environmental \\ Neurotoxicology, University of Tarapaca (UTA), Arica 1000000, Chile. Tel: 56-58-2-215420-124. E-mail: \\ dredilgren@aol.com
}

Received: September 28, 2018

Accepted: November 9, 2018

Online Published: December 11, 2018

doi:10.5539/ep.v8n1p18

URL: https://doi.org/10.5539/ep.v8n1p18

\begin{abstract}
Anthophyllite is an amphibole mineral formed through a prograde metamorphism of magnesium-rich ultramafic talcose rocks through increasing pressure and temperature and dehydration. The talc and anthophyllite are in phase equilibrium. Anthophyllite asbestos is therefore not a 'contaminant' of talc but a product derived from it. Fibrous talc, or so-called transitional fibers, are anthophyllite fibers undergoing retrograde degeneration. In its fibrous asbestiform state, anthophyllite differs in several fundamental ways from other commercially exploited forms of amphibole asbestos of which there are two broad families: monoclinic and orthorhombic. The more common forms of commercial amphibole asbestos such as crocidolite and amosite are monoclinic. The anthophyllites are orthorhombic. The differences between the two crystal systems are reflected at the level of the basic amphibole-structure in a greater overall fiber width dimensional profile and a significant reduction in microstructural strength. Strength reduction most probably arises at the cellular level and is particularly pronounced within the thinner population of fibers. Here microstructural differences, due in significant part to stacking defects in the basic amphibole structure, can account for these observations. The lack of an observed attendant mesothelioma risk following exposure to anthophyllite and transitional fibers in humans is a consequencel of these microstructural features that appear to differentiate them from the equidimensional monoclinic forms of amphibole asbestos such as South African crocidolite and amosite.
\end{abstract}

Keywords: anthophyllite, talc, fiber width, mesothelioma

\section{Introduction}

Anthophyllite asbestos differs from most forms of commercial amphibole asbestos in failing to demonstrate, on the basis of long term epidemiological studies, an attendant mesothelioma risk following exposure in humans (Ilgren and Hoskins, 2018a,b,c). We attribute this largely, though not completely, to its greater fiber width dimensional profile. The aim of this report is to provide several 'microscale' explanations for these 'macroscale' observations.

There are at least two points, not unrelated, that should be emphasized in this study. Anthophyllite is an amphibole mineral formed from the breakdown of talc in a prograde metamorphism of magnesium-rich ultramafic rocks through increasing pressure and temperature. The direct consequence of this is that anthophyllite does not 'contaminate talc'. Such 'contamination' has often been claimed with regard to cosmetic talc purity. The two minerals co-exist and are in phase equilibrium with each other; one does not 'contaminate' the other. Secondly, all amphiboles are known to occur in various structural forms; the fibrous, asbestiform, is comparatively rare to the extent its formation requires highly specific conditions of temperature, pressure and chemistry. Detailed micro-analytical studies of the talc-anthophyllite transformation have shown that the anthophyllite found in some transitional fibers, are part talc and part anthophyllite. In some cases, the transitional fibers form on asbestiform anthophyllite whilst in others they appear to form on non-asbestiform anthophyllite (McNamee \& Gunter, 2014). Since epidemiological studies of people exposed to asbestiform anthophyllite show that the mineral does not appear to pose a mesothelioma risk (see Ilgren \& Hoskins, 2018 
$\mathrm{a}, \mathrm{b}, \mathrm{c})$, it is logical to assume transitional fibers must also fail to present a mesothelioma risk. Moreover, since cleavage fragments are biologically inactive (Ilgren, 2004), transitional fibers formed on non-asbestiform, anthophyllite cleavage fragments are clearly not mesotheliomagenic.

\section{Microscale Observations of Anthophyllite}

Studies of fiber microstructure have answered many questions on the nature of, and differences in, the fibrosity and dimensions between different types of amphibole asbestos. For many years, structural detail was not easily detected by X-ray diffraction. The advent of high-resolution transmission electron-microscopy (HRTEM), opened new fields of knowledge (Busek \& Iijima, 1974). However, the application of HRTEM to amphibole asbestos initially posed a number of problems particularly as the electron diffraction patterns tended to be uninterpretable. The large numbers of reflections made it difficult to decipher their true identify due to the thick nature of the fibrils. Initially Hutchinson et al. $(1975,1979)$ addressed this by crushing fibres in a percussion mortar at liquid nitrogen temperatures to increase fibre brittleness. Subsequently, Busek and his colleagues overcame these technical difficulties (O'Keefe et al., 1978). The value of their work to the field was later extensively acknowledged including their ability to compute crystal structure images using HRTEM technology ${ }^{1}$.

\subsection{Fiber Width and Microstructure}

The microstructure of a typical amphibole mineral was first determined by Warren in 1930 on the basis of XRD. Later that year, the microstructure of anthophyllite was reported by the same workers (Warren \& Modell,1930). Technological limitations precluded further determination of the finer details of amphibole structure until Whittaker (1949) applied HRTEM methods to discern minor structural variation in an amphibole fiber (Whittaker, 1988, pers. comm.). Whittaker (1949) chose the anomalously wide fibers of Bolivian crocidolite for study since they approximated single crystals wide enough to be seen using optical microscopy enabling them to be mounted individually.

The fiber width dimensional profiles of Bolivian crocidolite and Finnish anthophyllite are both increased compared to other amphibole fibers (Ilgren et al., 2012) a reflection of their equally unusual modes of development. Commercially mineable deposits of anthophyllite are found in the field as ellipsoid lenses and seen in hand samples as radiating clusters (Fig. 1) compared with classical cross fiber deposits of South African crocidolite (Fig. 2).

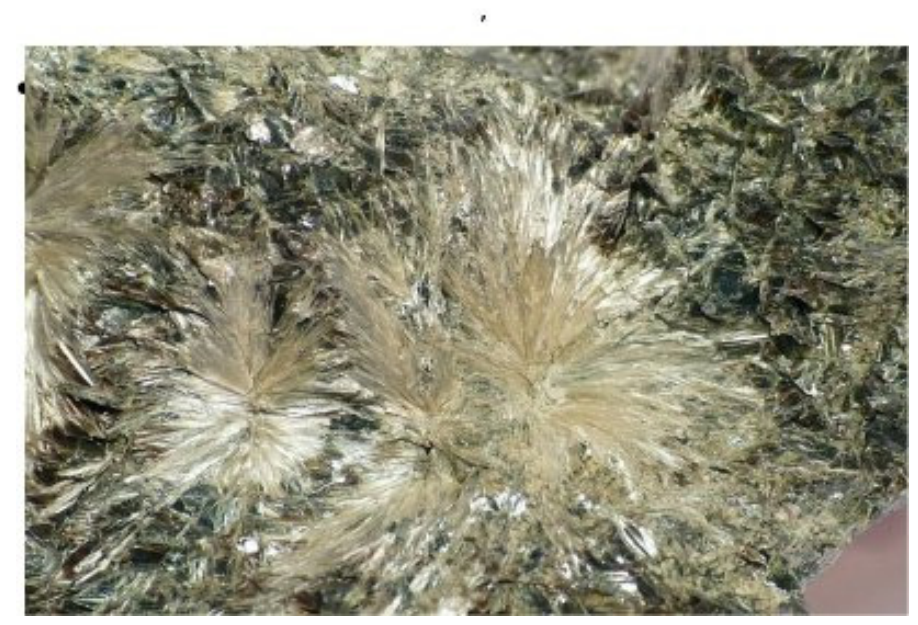

Figure 1. Finnish anthophyllite

\footnotetext{
${ }^{1}$ This was noted in a special issue of Nature milestones on crystallography (August 2014) and includes the contributions made by O'Keefe, Buseck, and Iijima.
} 


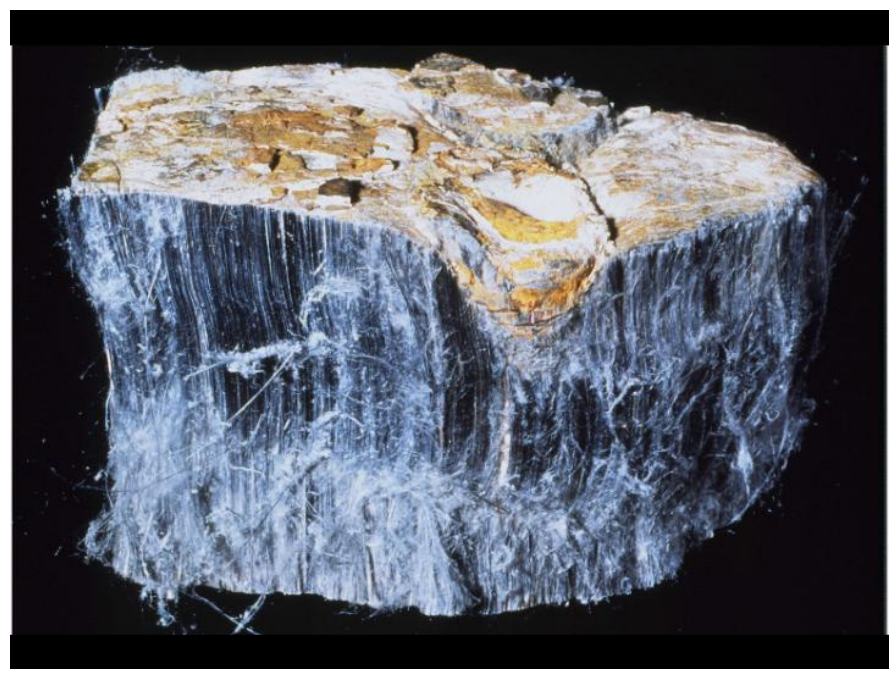

Figure 2. South African crocidolite

\subsection{Microstructural Variation reflected in Macroscopical Appearance}

The unusual macroscopic appearance of anthophyllite reflects underlying microstructural differences.

\subsection{Microstructural order and Increased Fiber Width}

The fibrils in amphibole asbestos form double chains with non-circular cross sections. The text book concept of amphibole microstructure has been seen historically as an ordered arrangement of laths composed of two chains of ribbons of $\mathrm{Si}_{4} \mathrm{O}_{11}$ units separated by a band of 7 cations. The idealized amphibole structure appears as a stack of I-beams on the (001) plane, in basal section, which form an ordered rectangular system in isometric projection (Fig 3) 

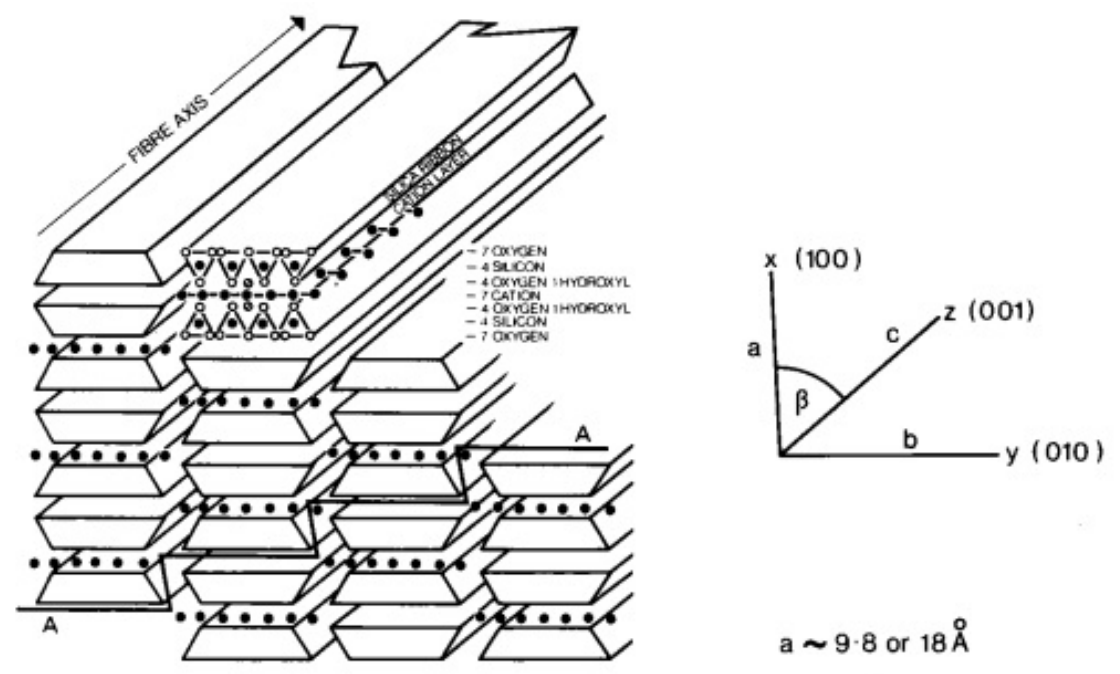

$$
\begin{aligned}
& a \sim 9.8 \text { or } 18 \AA \\
& b \sim 18 \AA \\
& c \sim 5.3 \AA \\
& \text { B } 101-106^{\circ}
\end{aligned}
$$

1 a.
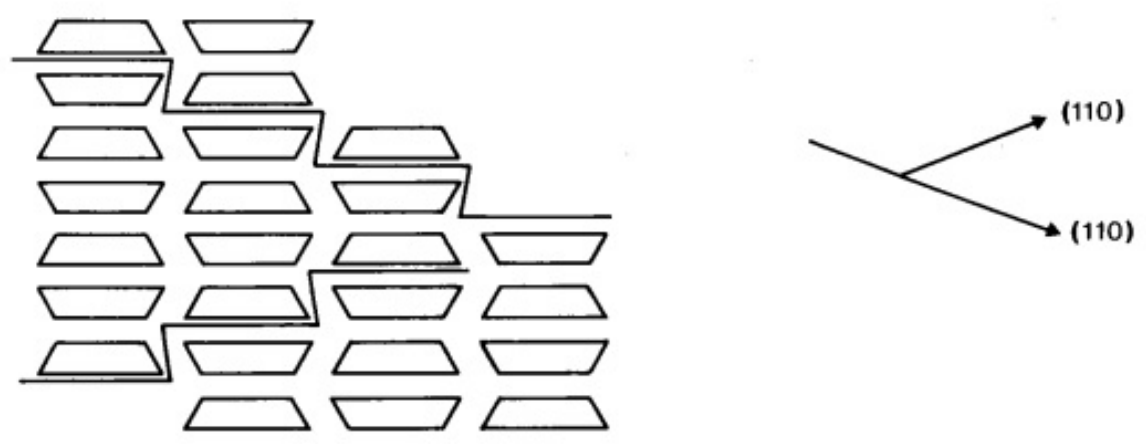

1b.

Figure 3. Stacking of I-beams (from Hodgson, 1986)

\subsection{Stacking Faults}

Changes in the arrangement of the basic structural blocks observed by X-ray diffraction differ according to the type of fibrous amphibole. These are known as stacking faults and they can alter fiber width. Thus, monoclinic amphiboles such as the classical South Africa crocidolite (Fig. 2) have three axes, all unequal in length, with two at right angles to each other and a third lying at an angle other than $90^{\circ}$. By contrast, the orthorhombic amphibole anthophyllite also has three unequal axes but they are all arranged at $90^{\circ}$ to each other. As a consequence, the distance ' $a$ ' in anthophyllite is twice that of ' $a$ ' found in South African Crocidolite, the angle of the alternating stacking sequence " $\beta$ " being $90^{\circ}$ (Fig. 4) (also see Dyar \& Gunter, 2018). 


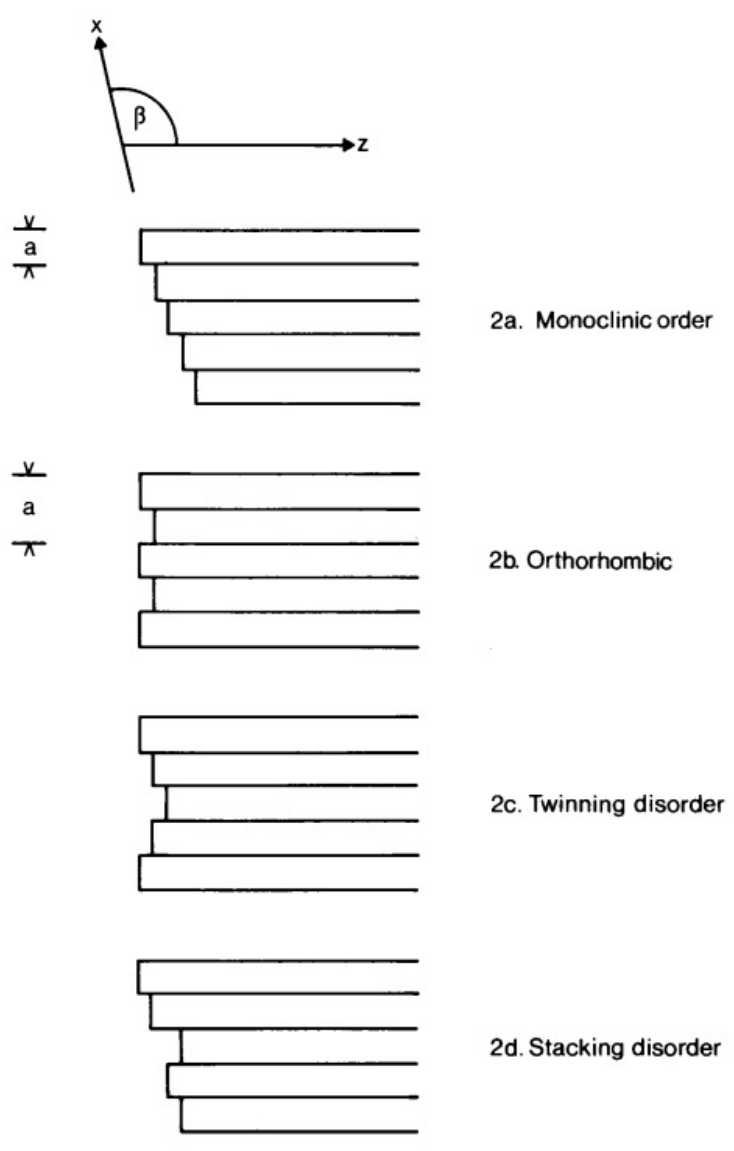

Figure 4. from Hodgson, 1986

\subsection{Wadsley Defects}

Changes in the construction of the basic structural blocks of fibrous amphiboles observed by X-ray diffraction are known as "Wadsley defects" (after Wadsley, 1955). These can affect fibre width e.g. through the insertion of "triple chain defects" in the centre of each "unit cell" (e.g. see Figure 1 in Veblen \& Busek (1980) ) (Fig. 5). Indeed, anthophyllite appears to contain more triple chain defects than monoclinic amphiboles. Many of the structural changes involved in the retrograde reaction of anthophyllite to talc also involve chain width errors also known as 'Wadsley defects', a "conclusion supported by the microstructures observed with electron microscopy." (Veblen and Busek, 1980) Wadsley defects can thus alter structural integrity ${ }^{2}$ that provide sites for ion migration which can, in turn, initiate structural reordering to a sheet silicate such as talc. The bases for such alteration mechanisms have been studied for more than 70 years and have led to the conclusion that anthophyllite and talc are in phase relationship with each other. The alteration of anthophyllite to fibrous talc is the initial phase of this alternation process (Virta, 1985; Veblen \& Busek, 1980). "The crystallographic relationship between the fibrous talc and amphibole and the fine intermixing of the two minerals are consistent with such an alteration mechanism" (Virta, 1985) "talc being intergrown on a nanoscale with anthophyllite" as part of this process" (Wylie et al., 1997). 'Intermediate or transitional fibers are fibers of anthophyllite caught in the mostly complete retrograde metamorphosis to talc' (Crane, 2000); "the fibril dimensions and dominant (100) orientation of the amphibole lattice, suggesting that the fibrous morphology is due to the altedration of fibrous, if not asbestiform, anthophyllite (Virta, 1985).

\footnotetext{
${ }^{2}$ Virta (1985) also says that "Defect structures in the lattice structure parallel to the $b^{*}$ direction of amphibole suggested by the streaking observed in the ED patterns are also consistent with the chain width disorder of chain silicate alteration described by Veblen (1980)".

3 "Anthophyllite is present only within the fibrous talc grains. The intermixing of the talc and anthophyllite on a submicroscopic scale and the crystallographic relationship between the talc and anthophyllite crystal lattices suggest an alteration mechanism similar to that observed in the formation of some biopyriboles. (Virta, 1985)"
} 


\section{Mechanisms for the Reaction of Anthophyllite to Talc}

Veblen \& Busek (1980) suggested several mechanisms for the reaction of anthophyllite to talc. One is the replacement of anthophyllite along grain boundaries by talc mentioned above. Another is through the insertion of 'very wide chains' e.g. triple chain defects (vs). Veblen \& Busek (1980) say the reaction can occur by 'the nucleation and growth of wide chain zippers'. but caution the reader not to interpret the word "zipper" as a 'two dimensional' change but view them as 'three dimensional slabs" ${ }^{4}$ or very large defects that are usually extensive in both the $a$ and $c$ directions'. These defects create large channels parallel to the c-axis that "are thus enormous compared with the sizes of the ions that must diffuse in and out of the structure during hydration reaction" (to talc). "Presumably these channels are empty or filled to a very low atomic density." (Veblen \& Busek, 1980) However as material accumulates or 'nucleates' within such channels, it may attain a critical size after which it will continue to "grow consuming anthophyllite" (Veblen \& Busek, 1980). This occurs "With falling metamorphic temperature, (when) wide chain material may well become more stable than double-chain silicate" (anthophyllite). Thus, "once conditions have left the range for anthophyllite stability and have become appropriate for the stability of talc",(Veblen \& Busek, 1980). a 'transitional fiber' or talcbole will form as a pseudomorph on the original anthophyllite fiber and a continuum of structures between what one calls chain silicate and platey talc will eventuate (Santii, 2015 pers com).

The distribution of defective and perfect anthophyllite indicates that the reaction is initiated quite locally, "two such areas of concentrated defects (interpreted) to be in the first stages of reaction toward talc" being illustrated by Veblen and Busek in their 1980 paper (see: figure 22 of HRTEM images. Veblen \& Busek1980) ${ }^{6}$

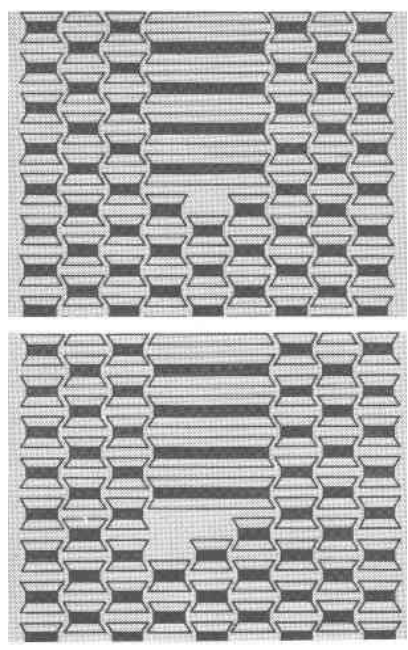

Figure 5. Adapated from Figure 1 in Veblen \& Busek, 1980. Two different termination types for sextuple-chain zippers in anthophyllite shown in the I-beam representation

\subsection{The Chemical or Physical Parameters Responsible for the Initiation of the Reaction}

The chemical or physical parameters responsible for the initiation of the reaction are not understood. Possibly, once an area has started to react, minor structural stresses resulting from the defects further destabilize the anthophyllite. Alternatively, the pattern of reaction may be controlled by externally imposed 'chemical potential variation'. Amongst such 'externally imposed chemical variations' might be the 'weathering' discussed in detail in Part 3 of this series on American and Japanese anthophyllite. Thus, anthophyllite from the surface of deposits was known to be more fibrous and was sometimes left on the surface longer before collection to enhance its "fibrosity" and making it soft enough to mine.

\subsection{Mechanisms of Internal Transport that Facilitate the Reaction of Anthophyllite to Talc}

Most forms of monoclinic amphibole do not permit the passage of chemicals and fluids and are thus viewed as 'closed systems'. Anthophyllite is unusual since it has an 'open' system through which materials can diffuse along grain boundaries and structural tunnels that can change its durability and width. The "grain boundaries"

\footnotetext{
${ }^{4}$ Or unit size structures of amorphous material.

${ }^{5}$ Veblen \& Busek (1980) illustrate 'zipper terminations' as large 'defects' based on detailed X-ray diffraction studies of anthophyllite.

${ }^{6}$ A very difficult to discern X Ray diffraction pattern.
} 
mentioned above along which talc may migrate in anthophyllite do not appear to be found in monoclinic amphiboles such as crocidolite. (Cressey et al, 1991; Ahn and Busek, 1991). The large defects also mentioned above in anthophyllite can create large channels parallel to the c-axis that "are enormous compared with the sizes of the ions that must diffuse in and out of the structure during the hydration reaction (to talc)". The diffusion of cations in silicates is generally a sluggish process but there are some structures in which it can be extremely rapid, most notably where large tunnels present. The introduction of wide-chain silicates can thus provide pathways for ultra-fast diffusion. Indeed, since the complete conversion of anthophyllite to talc only requires removal of one-seventh of the octahedral cations, this reaction step can sometimes be extremely rapid. Indeed, it is likely that diffusion along zipper terminations is still more rapid, especially at metamorphic temperatures. By analogy with zeolites, the ion exchange required for zipper expansion can conceivably take place on time scales of minutes, suggesting that the diffusional constraint on the growth of zippers may not even be significant (particularly since most of the cations do not need to move in or out of the structure at all). Diffusion rates probably pose no problems for the growth of (210)-talc, because cations could easily move along the sheet terminations of the growth ledges and along the talc-pyribole interface.

\subsection{The Range of Conditions Required for Anthophyllite Formation and Stability}

The range of conditions required for anthophyllite formation and stability have been studied for more than 70 years. The not uncommon co-existence of the conditions required for anthophyllite and talc formation explain why the two often occur together. This is well illustrated in fig 11 of Neathery's (1968) study of talc and anthophyllite in Alabama (Fig. 6) both topographically in the field (upper part of illustration) and experimentally in the laboratory (lower part).
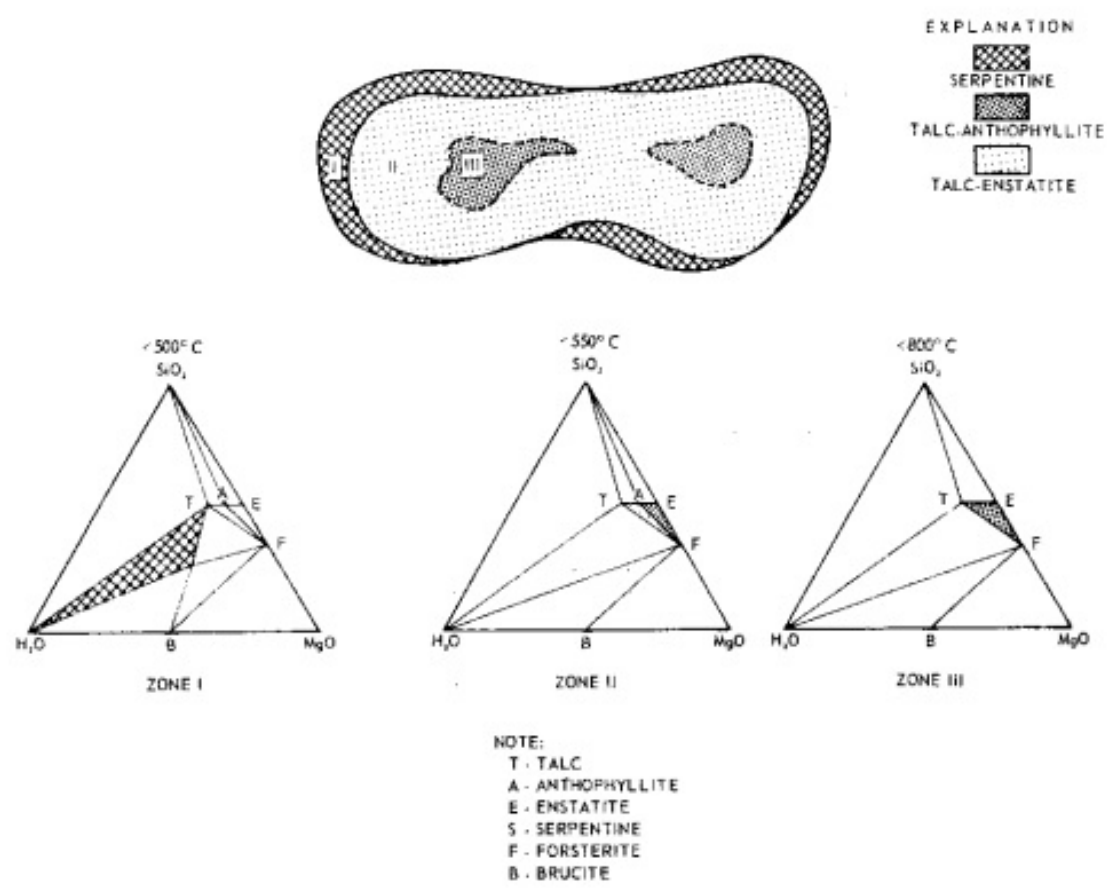

Figure 6. Principal zones of a typical talc-anthophyllite-bearing ultramafic body, and diagrams of stable mineral phases in the principal zones. (Figure 11 from Neathery (1968)).

\subsection{Experimental Studies of the Phase Stability Relationship between Anthophyllite and Talc}

The experimental studies of phase equilibrium for anthophyllite formation have been studied by various workers most notably Bowen \& Tuttle (1949), Yoder (1952), Roy \& Roy (1955), Fyfe (1962), Greenwood (1963), and Kitahara, Takenouchi \& Kennedy (1966). As Neathery (1968) said "The physicochemical conditions involved in the formation and alteration of the talc and anthophyllite are discussed" ... since "this discussion should aid in understanding the occurrence of talc and anthophyllite in the ultramafic rocks". A significant part of Bowen and Tuttle's studies (1949) dealt with the interrelations of the phases talc and anthophyllite and an illustration of a 
hydration-dehydration sequence illustrating their basic relationship was given. Bowen \& Tuttle (1949) were thus able to produce anthophyllite in the presence of water vapor only as a metastable phase by heating talc at $800^{\circ} \mathrm{C}$ and under a pressure of 15,000 psi for an hour; ... They concluded that anthophyllite formed only a transient phase in the presence of water vapor in the alteration of enstatite to talc. Bowen \& Tuttle (1949) concluded that "Talc was found to form readily below $800^{\circ} \mathrm{C}$ at water pressures between 6,000 and 30,000 psi. At temperatures above $800^{\circ} \mathrm{C}$ talc appeared as a metastable product with forsterite (magnesium olivine) and enstatite. Below $800^{\circ} \mathrm{C}$ in water deficient systems where talc is a stable product, anthophyllite occurred but was found to be always partially altered to talc" and will thus "develop as an intermediate phase in the formation of talc from anhydrous material." Yoder (1952) and Roy and Roy (1955) also concluded that anthophyllite was a stable phase of the system $\mathrm{MgO}-\mathrm{SiO}_{2}-\mathrm{H}_{2} \mathrm{O}$ only in water deficient regions. Yoder $(1952$, p. 599) concluded, on the basis of experimental data, that the upper limit of talc stability lies near an invariant point at $795^{\circ} \mathrm{C}$. Yoder $(1952, \mathrm{p} .612)$ surmised that anthophyllite would remain stable at temperatures below $660^{\circ} \mathrm{C}$ in 'water deficient systems'. Neathery (1968) summarized the work by Fyfe (1962) who in a study of the relative stability of talc, anthophyllite, and enstatite, experimentally showed that anthophyllite was not a transient phase but that the reactions involving the formation and dehydration of anthophyllite were "sluggish". He experimented over a limited range of conditions between $670^{\circ} \mathrm{C}$ at 2,000 bar pressure and found it possible to convert talc to anthophyllite/quartz in the presence of water and enstatite/quartz to anthophyllite in the presence of water. Complete conversion of talc to anthophyllite and enstatite to anthophyllite was achieved at temperatures near $760^{\circ} \mathrm{C}$ in the presence of excess water.

\section{Macroscopic Representations of the Experimental Observations}

Reading Säntti et al. (2006), (2015 pers com) can help one understand how macroscopic observations can explain the aforementioned microscale experimental findings. Using the area from the Eastern border of Finland west to Paakilla, known as Outokumpo - Jormua Ophiolite Belt or OJOB, the area transitions from a largely talc mining zone to anthophyllite across four zones A through D (Fig. 7. See fig. 1, Säntti et al., (2006) reproduced below) demarcated by the lines marked 1 through 4 . Paakilla is just to the left of line 3 at the level of Otokumpo; the black streaks are anthophyllite. Nearly pure talc is found in the East along line 1. The legend in the top right-hand corner of the figure refers to the zones and is self explanatory:

(1) "talc in" (meaning that zone is nearly all talc);

(2) "prograde talc, carbonate out" (meaning with the loss of carbonate, talc being degraded);

(3) "anthophyllite in" (unstated, talc basically gone).

Säntti (2015, pers. comm.) said that the process of talc degradation to anthophyllite formation going from East to West involves progressive dehydration and a macroscale increase in temperature and pressure which he likened to the "wringing" out of a highly-heated towel (the talc sheet silicate) in a magnesium - silica rich environment causing it to undergo dehydration and chain silicate formation. 


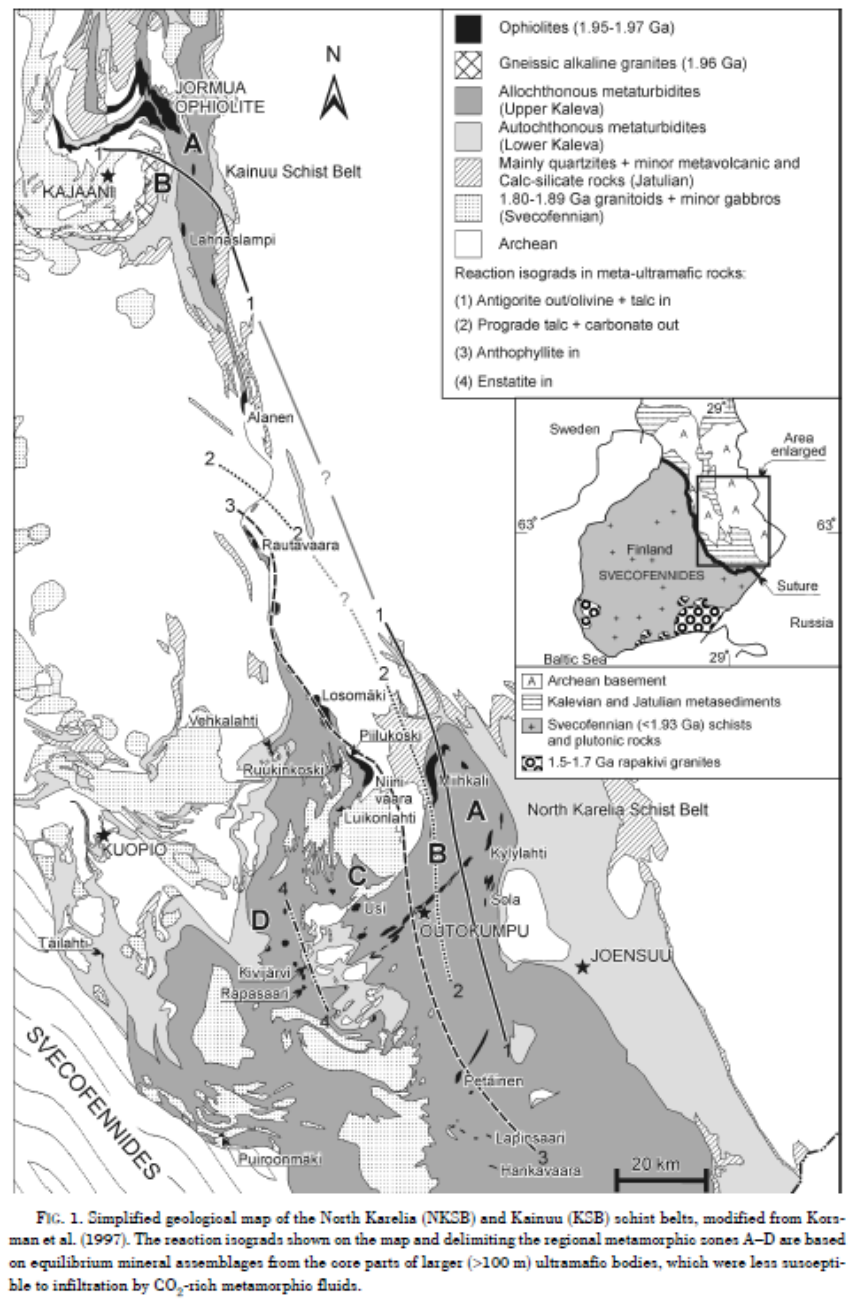

Figure 7. fig. 1, ex. Säntti et al., (2006)

\section{Biological Implications of the Observed Microstructural Findings}

\subsection{Increased Fiber Width - Pleural Transloction}

Fiber width may be a major factor in controlling the translocation of respirable fibers from the lung to the pleura (e.g. Wylie (2016) Paoletti and Bruni, (2009)). Fibers less than $0.3 \mu \mathrm{m}$ (Carbone et al., 2012) to $0.4 \mu \mathrm{m}$ (Lentz et al., 2003) wide are more readily translocated to the pleura and consequently associated with an increased mesotheliomagenic potential (Wylie et al. (1993) ${ }^{7}$. Indeed, "The percentage of elongated mineral particles, citing anthophyllite as an example (Wylie, 2016) that are longer than $10 \mu \mathrm{m}$ with widths less than $0.33 \mu \mathrm{m}$ as a proxy for potency, yields a $0 \%$ (potency proxy) for anthophyllite" implying "no mesothelioma risk from anthophyllite asbestos (Wylie, 2016)".

\subsection{Reduced Fiber Tensile Strength and Durability - Decreased Biopersistence}

Both stacking faults and Wadsley defects can weaken intrinsic fiber strength and potentially account for anthophyllite's reduced tensile strength in relation to monoclinic amphiboles. If amphibole fibres are defective, they may break at stress levels well below their par value "tensile strength". Fibre tensile strength measurements available for South African and Western Australian crocidolite emphasize their great strength. By contrast, the tensile strengths of Bolivian crocidolite and Finnish anthophyllite asbestos are much weaker. The multiplicity of microdefects in Bolivian crocidolite and Finnish anthophyllite asbestos fibres may account for these differences

\footnotetext{
${ }^{7}$ Wylie (2016) also said topographic features "on the scale of a few hundred nanometers" could also influence translocation by altering "the rate and direction of cellular movement" (Driscoll et al. 2014, Sun et al. 2015) thus emphasizing the multivariable influence of microstructural disorder.
} 
in tensile strength. Indeed, Zoltai (1982) said "The higher internal strength of crocidolite also appears to be in accord with the observed lower density of chain width defects in South African crocidolite than in anthophyllite". Tensile strength data confirming this indicate that the South African crocidolite fiber tensile strength $\left(\mathrm{MN} \mathrm{m}^{3}\right)$ $(2735-4648)$ is indeed significantly greater than Finnish anthophyllite $\left(1323 \mathrm{MN} \mathrm{m}^{3}\right)$ and Bolivian Crocidolite (1434 $\mathrm{MN} \mathrm{m}^{3}$ ). Hodgson (1986) infers this may be due to the greater "the multiplicity or otherwise of micro defects in the structure of individual fibres". The biological relevance of such observations to differential potency in mesothelioma induction can only, at this stage, be hypothesized. However, one interpretation could be that the "muscular" cytoskeleton of the macrophage could conceivably break a "brittle" fibre far more easily than one that is thin, strong, defect free and highly flexible. If that were so, then the macrophage could far more readily clear brittle fibers than those of much greater internal strength.

\section{Frequency of Transitional Talc Fibers and their Relevance to Regulatory Policy}

Crane (op cite Price 2010) said transitional objects are "for the most part fibers of industrial talc" rarely found in commercial cosmetic talcum powders (Lee \& Van Orden, 2014). OSHA (Price, 2010) said that OSHA 'does not believe that independent evidence of their health exists which would support regulation". We must agree. Therefore, if as Crane says (op cite Price, 2010) that the large numbers of transitional fibers found in industrial talcs are much longer the 20 to 1 to nearly 100 to 1 in aspect ratio, we would argue that even if these were composed of a significant percentage of anthophyllite e.g. at the start of retrograde metamorphism to talc, the failure to observe a mesothelioma risk to humans on the basis of the epidemiology (Ilgren and Hoskins, 2018 a, $\mathrm{b}, \mathrm{c})$, surely indicates that they would certainly not pose any such risk as well.

Wylie et al. (1997) said transitional fibers in a mineralogical state of growth between anthophyllite fiber and talc are particularly common in some deposits (e.g. Gouverneur District New York State talc marketed under the trade name Nytal in which $14 \%$ of the talc was intergrown with anthophyllite in reference to their analysis of commercial sample FD14).

\subsection{Tremolite and Transitional Fibers}

The data indicate that anthophyllite, rather than tremolite, is the major amphibole occurring in the fibrous talc grains (Virta, 1985) and little, if any, was present within the fibrous talc grains.

\section{Claims that Anthophyllite Asbestos Causes Mesothelioma in Humans}

Lemen (2015), in a conference presentation entitled "Asbestos fiber toxicities", suggested several times that anthophyllite was able to produce mesothelioma. For example, in a slide concerning a paper by Oksa and Pukkala (1997) "examining process products composed of chrysotile" he said that out of a cohort of 8,391 members of the Finnish Locomotive drivers' association during the years 1953 and 1991 there was a statistically significant four-fold risk of mesothelioma amongst men exposed to anthophyllite asbestos contaminated with tremolite and exposed pipes used in the locomotives, made of chrysotile". Since crocidolite and amosite were the amphiboles historically used for insulation in trains and on pipes together with other commercial materials, particularly as reflected in various Finnish lung burden studies, undermines Lemen's claims.

Dodson et al. (2005) assessed the lung burdens of cases of mesothelioma from individuals in different parts of the United States. One case had only anthophyllite fibers (case L-28) at a total concentration of 3,159,370 f/gram dry lung of which $8 \%$ were Stanton sized. The case, a 46-year old woman, was said to have been exposed while a company was doing reconstruction of a facility. Whilst this implied bystander - environmental exposure, the fibre level was well into the occupational range. Moreover, the young age of the case and the time between diagnosis and death (four years) cast doubt on the diagnosis. Alternate causes of exposures were also not excluded.

Hull et al. (2002) reported two mesotheliomas among workers in what they claim to be "asbestiform fiber" bearing talc mines in New York State. No anthophyllite was found in one while the tremolite levels were very high. The anthophyllite concentration found in the other case was 5 million f/gm and whilst the aspect ratio was 90 this was only based on the analysis of 6 fibers. This case was also diagnosed as having asbestosis in addition to the mesothelioma but the corresponding fiber concentration of 7 million $\mathrm{f} / \mathrm{gm}$ is generally considered to be insufficient to produce asbestosis and the role of the tremolite cannot be excluded.

Rom et al. (2001) reported a mesothelioma case allegedly due to environmental childhood exposure to anthophyllite from exposures near an American factory using anthophyllite fibers exclusively from 1964 to 1972. A lung burden study was supposedly done but the fibre concentration data are not given. They only said anthophyllite fibers $>5 \mu \mathrm{m}$ in length were found using TEM-XRD-SAED. which differed from the average length of anthophyllite fibers from the general population (cited as $2.97 \mu \mathrm{m}$ ) (Dodson et al., 1999, 2000). They 
also say The Finnish Institute of Occupational Medicine in 1990 reported two mesothelioma patients with only anthophyllite in their lung tissue (Hernberg et al., 1990) but crocidolite exposure cannot be excluded. Kottek and Kilpatrick (2002) also independently critiqued Rom et al. (2001) and pointed out a number of its weaknesses.

Korchevsky et al. (2008) published a study of four mining districts in Russia one of which allegedly produced anthophyllite asbestos. The authors claimed that their revision of the risk factor for anthophyllite and mesothelioma suggested it was far more toxic than previously reported. The anthophyllite was allegedly from the Sistert mining and milling area. Their conclusions were almost certainly confounded by the presence of other types of amphibole asbestos, a near total lack of any epidemiological data, and the association with historical dust levels that were simply beyond "snow storm conditions" (up to $900 \mathrm{f}-\mathrm{cc}$ ).

\subsection{Experimental Animal Observations and their Relevance to Mesothelioma Risk Assessment}

An extensive review of the worlds literature on animal mesothelioma (Ilgren, 1993) revealed one long term rodent inhalation study of Finnish anthophyllite. Two mesotheliomas were found at the two highest dose levels $(10-11$ $\mathrm{mg} / \mathrm{m}^{3}$ ), one after one year and the other after two years exposure. Whilst the fiber per cc equivalents of these mass doses were not provided by the authors (Wagner et al, 1974), the doses are astronomical easily in excess of 5,000 $\mathrm{f} / \mathrm{ml}$ (Ilgren \& Browne, 1991). Such astronomical fiber and dust mass levels would not surprisingly have the ability to produce mesotheliomas but be of little relevance to virtually any encountered historically in humans. In addition, if anthophyllite was truly a potent fiber for mesothelioma one would expect a very high percentage of mesotheliomas such as found with erionite (Wagner et al., 1985). However, this is not seen. Moreover, as Wagner et al. (1987) said the finding of one background mesothelioma even in these animal studies is not at all surprising, the finding of two mesotheliomas given the exposure parameters undermines the strength of these findings.

\section{Conclusions}

Anthophyllite is an amphibole mineral formed from prograde metamorphism of talc in magnesium-rich ultramafic rocks through increasing pressure and temperature and dehydration. The transition is dynamic and reversible so the opposite, retrograde, process can also occur. The detailed mechanism of the transition of talc to/from anthophyllite has been extensively studied for many decades. Likewise, the structure of anthophyllite itself. Anthophyllite in its asbestiform fibrous state differs in important fundamental ways from other commercially exploited fibrous asbestiform amphiboles. At the cellular level anthophyllite is orthorhombic while the other amphiboles are monoclinic. Such a difference in the basic amphibole-structure can account for the greater dimensional fiber width seen with anthophyllite asbestos and the reduction in strength found in the thinner fibers. Microstructural differences such as the stacking defects which occur and their consequences seen in the basic amphibole structure of anthophyllite asbestos may account for both the reduction in fiber strength and the increase in width. These factors are important since it is thinner fibres that would be expected to be the most biopotent as fiber width may be a major factor in the translocation of fibers from lung to pleura. The microstructural differences between anthophyllite and other amphiboles probably account for the apparent lack of an attendant mesothelioma risk to humans following even heavy exposure to anthophyllite asbestos in occupational settings as observed in the long term epidemiological studies made particularly in the United States and in Finland. Animal experimentation reflected these findings even after enormous dose levels of fibre.

\section{References}

Ahn, J. H., \& Busek, P. E. (1991). Microstructures and fiber-formation mechanisms of crocidolite asbestos. American Mineralogist, 76(9), 1467-1478.

Bowen, N. L., \& Tuttle, T. F. (1949). The system $\mathrm{MgO}-\mathrm{SiO}_{2}-\mathrm{H}_{2} \mathrm{O}$. Bull. Geological Society of America, 60, 439-60.

Buseck, P. R., \& Iijima, S. (1974). High resolution electron microscopy of silicates. American Mineralogist, 59, 1-21.

Carbone, M. et al. (2012). Malignant mesothelioma: Facts, myths and hypotheses. Journal of Cell Physiology, $227,44-58$.

Crane, D. T. (2000). Background information regarding the analysis of industrial talcs, edited by U.S. Department of Labor Occupational Safety and Health Administration: OSHA.

Dodson, R. F., Atkinson, M. A. L., \& Levin, J. L. (2003). Asbestos fiber length as related to potential pathogenicity: A critical review. American Journal of Industrial Medicine, 44, 291-297.

Dodson, R. F., Graef, R., Shepherd, S., O'Sullivan, M., \& Levin, J. (2005). Asbestos burden in cases of mesothelioma from individuals from various regions of the United States. Ultrastructural Pathology, 29, 415-433. 
Dodson, R. F., Williams, M. G., Huang, J., \& Bruce, J. R. (1999). Tissue burden of asbestos in nonoccupationally exposed individuals from east Texas. American Journal of Industrial Medicine, 35(3), 281-286.

Driscoll, M. K., Sun, X., Guven, C., Fourkas, J. T., \& Losert, W. (2014). Cellular Contact Guidance through Dynamic Sensing of Nanotopography. ACSNano, 8(4), 3546-3555.

Dyar, M. D., \& Gunter, M. E. (2018). Mineralogy and Optical Mineralogy, Chapter 22, pp. 577-640. Mineralogical Society of America, Chantilly, Virginia.

Fyfe, W. S. (1962). On the relative stabilities of talc, anthophyllite, and enstatite. American. Journal of Science, $260,460-46$.

Greenwood, H. J. (1963). The synthesis and stabitity of anthophyllite. Journal of Petrology, 4, 317-351.

Hernberg, S., Tuomi, T., Tammilehto, L., Huuskonen, M., \& Virtamo, M. (1990). Mesothelioma and exposure to asbestos: final report to Finnish Work Environment F Gunter und 86081. Institute of Occupational Health, Helsinki (in Finnish).

Hodgson, A. A. (1986). Scientific advances in asbestos, 1967 to 1985. Crowthorne, United Kingdom, Anjalena Publications Ltd., 186 pp.

Hull, M. J., Abraham, J. L., \& Case, B. W. (2002). Mesothelioma among Workers in Asbestiform Fiber-Bearing Talc Mines in New York State. The Annals of Occupational Hygiene, 46(suppl_1), 132-135.

Hutchinson, J. L., Irusteta, M. C., \& Whittaker, E. J. W. (1975). High resolution electron microscopy and diffraction studies of fibrous amphiboles. Acta Crystalliographica, A31, 794-801. https://doi.org/10.1107/S0567739475001714

Hutchinson, J. L., Nissen, H.-U., \& Wessicken, R. (1979). Observation of talc tremolite interfaces by high resolution electron spectroscopy. Physics and Chemistry of Minerals, 4, 275-280.

Ilgen, E. B. (2004). The Biology of Cleavage Fragments: A Brief Synthesis and Analysis of Current Knowledge. Indoor \& Built Environment, 13(5), 343-356. https://doi.org/10.1177/1420326X04047563

Ilgren, E. B. (1993). Mesotheliomas of animals: A comprehensive, tabular compendium of the world's literature CRC Press, Boca Raton, Fla.

Ilgren, E. B., \& Browne, K. (1991). Asbestos-related mesothelioma: Evidence for a threshold in animals and

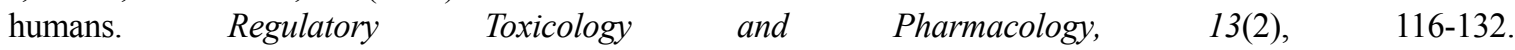
https://doi.org/10.1016/0273-2300(91)90017-P

Ilgren, E. B., \& Hoskins, J. A. (2018a). Anthophyllite Asbestos: The Role of Fiber Width in Mesothelioma Induction Part 1: Epidemiological Studies of Finnish Anthophyllite Asbestos. Environment and Pollution, 7(1), 9-23.

Ilgren, E. B., \& Hoskins, J. A. (2018b). Anthophyllite Asbestos: The Role of Fiber Width in Mesothelioma Induction Part 2: Further epidemiological studies of occupational, domestic and environmental exposure to Finnish Anthophyllite asbestos. Environment and Pollution, 7(1), 24-35.

Ilgren, E. B., \& Hoskins, J. A. (2018c). Anthophyllite Asbestos: The Role of Fiber Width in Mesothelioma Induction Part 3: Studies of American and Japanese Anthophyllite Asbestos - Additional Supportive Evidence. Environment and Pollution, 8(2).

Ilgren, E. et al. (2012). Fiber Width as a Determinant of Mesothelioma Induction and Threshold - Bolivian Crocidolite: Epidemiological Evidence from Bolivia -Mesothelioma Demography and Exposure Pathways. Annals of Respiratory Medicine.

Kitahara, S. H., Takenouchi, S., \& Kennedy, G. C. (1966). Phase relations in the system MgO-SiO2-H2O at high temperatures and pressures. American Journal of Science, 264, 223-233.

Korchevskiy, A., Rasmuson, E., Rasmuson, J., \& Strode, R. (2013). Asbestos mining in Russia: approaches to public health risk assessment: Its all about people, pre-prints of the Society for Mining, Metalurgy, and Exploration. Annual Meeting, Denver, Colorado.

Kottek, \& Kilpatrick. (2002). Re: malignant mesothelioma from neighborhood exposure to anthophyllite asbestos. American Journal of Industrial Medicine, 41(6), 514. https://doi.org/10.1002/ajim.10071

Lemen. (2015). Conference presentation: "Asbestos fiber toxicities" (available on request). 
Lentz, T., Rice, C. H., Succop, P., Lockey, J. E., Dement, J. M., \& Lemasters, G. (2003). Pulmonary Deposition Modeling with Airborne Fiber Exposure Data: A Study of Workers Manufacturing Refractory Ceramic Fibers. Applied occupational and environmental hygiene, 18(4), 278-88.

McNamee, B. D., \& Gunter, M. E. (2014). Compositional Analysis and Morphological Relationships of Amphiboles, Talc and Other Minerals Found in the Talc Deposits from the Gouverneur Mining District, New York (Part 2 of 2). The Microscope, 62(1), 3-13.

Neathery, T. L. (1968). Talc and anthophyllite asbestos deposits in Tallapoosa and Chambers Counties, Alabama: Alabama: Geological Survey of Alabama Bulletin 90, 98 p.

O'Keefe, M. A., Buseck, P. R., \& Iijima, S. (1978). Computed crystal structure images for high resolution electron microscopy. Nature, no. 5669. 274:322-324.

Oksa, P., Pukkala, E., Karjalainen, A., Ojajärvi, A., \& Huuskonen, M. S. (1997). Cancer incidence and mortality among Finnish asbestos sprayers and in asbestosis and silicosis patients. American Journal of Industrial Medicine, 31 , 693-698. https://doi.org/10.1002/(SICI)1097-0274(199706)31:6<693::AID-AJIM4>3.0.CO;2-S

Paoletti, L., \& Bruni, B. M. (2009). Caratterizzazione dimensionale di fibre anfiboliche nel polmone e nella pleura di casi di mesothelioma da esposizione ambientale. (Dimensional characterization of amphibole fibers in the lung and in the pleura of mesothelioma cases from environmental exposure.) Medicina del Lavoro, 100, 11-20.

Price, B. (2010). Industrial-grade talc exposure and the risk of mesothelioma. Critical Reviews in Toxicology, 40(6), 513-530.

Rom, W. N., Hammar, S. P., Rusch, V., Dodson, R., \& Hoffman, S. (2001). Malignant mesothelioma from neighborhood exposure to anthophyllite asbestos. American Journal of Industrial Medicine, 40, 211-214.

Roy, D. M., \& Roy, R. (1955). Synthesis and stability of minerals in the system $\mathrm{MgO}-\mathrm{Al}_{2} \mathrm{O}_{3}-\mathrm{SiO}_{2}-\mathrm{H}_{2} \mathrm{O}$. American Mineralogist, 40, 147-178.

Säntti, J., Kontinen, A., Sorjonen-Ward, P., Johanson, B., \& Pakkanen, L. (2006). Metamorphism and Chromite in Serpentinized and Carbonate-Silica-Altered Peridotites of the Paleoproterozoic Outokumpu-Jormua Ophiolite Belt, Eastern Finland. International Geology Review, 48(6), 494-546. https://do,223-233.i.org/10.2747/0020-6814.48.6.494

Sun, X. Y., Driscoll, M. K., Güven, C., Satarupa, D., Parent, C. A., Fourkas, J., \& Losert, W. (2015). Asymmetric nanotopography biases cytoskeletal dynamics and promotes unidirectional cell guidance. Proc. National Academy of Sciences, 112(41).

Veblen, D. R., \& Buseck P. B. (1980). Microstructures and Reaction Mechanisms in Biopyriboles. American Mineralogist, 65, 599-623.

Virta, R. L. (1985). The phase relationship of talc and amphiboles in a fibrous talc sample. Report of investigations 8923 / US Dept. of the Interior, Bureau of mines.

Wagner, J. C., Berry, G., Skidmore, J. W., \& Timbrell, V. (1974). The effects of the inhalation of asbestos n rats. British Journal of Cancer, 29, 252-269.

Wagner, J. C., Skidmore, J. W., Hill, R. J., \& Griffiths, D. M. (1985) Erionite exposure and mesotheliomas in rats. British Journal of Cancer, 51, 727-730.

Wagner, J., Griffiths, G., \& Munday, D. (1987). Experimental studies with palygorskite dusts. British Journal of Industrial Medicine, 44, 749-763.

Warren, B. E., \& Modell, D. I. (1930) The structure of anthophyllite $\mathrm{H}_{2} \mathrm{Mg}_{7}\left(\mathrm{SiO}_{3}\right)_{8}(\mathrm{OH})_{2}$ Zeits. Krist., 75 , 161-178.

Whittaker, E. J. W. (1949). The structure of Bolivian crocidolite. Acta Crystallographia, 2, 312-317. https://doi.org/10.1107/S0365110X49000801

Wylie, A. G. (2016). Amphibole dusts: Fibers, Fragments and Mesothelioma. The Canadian Mineralogist, 54, 1403-1435.

Wylie, A. G., Bailey, K. F., Kelse, J. W., \& Lee, R. J. (1993). The importance of width in asbestos-fiber carcinogenicity and its implications for public policy. American Industrial Hygiene Association Journal, 54(5), 239-252. 
Yoder, H. S. Jr. (1952). The $\mathrm{MgO}-\mathrm{Al}_{2} \mathrm{O}_{3}-\mathrm{SiO}_{2}-\mathrm{H}_{2} \mathrm{O}$ system and the related metamorphic facies. American Journal of Science Bowen, 569-627.

Zoltai, T. (1982). Amphibole asbestos mineralogy. Reviews in Mineralogy and Geochemistry, 9A(1), 237-278.

\section{Copyrights}

Copyright for this article is retained by the author(s), with first publication rights granted to the journal.

This is an open-access article distributed under the terms and conditions of the Creative Commons Attribution license (http://creativecommons.org/licenses/by/4.0/). 